\title{
KAIMO PRADINIŲ KLASIŲ MOKSLEIVIŲ SVEIKATOS IR JŲ UGDYTOJŲ SVEIKATOS NUOSTATOS SĄSAJOS
}

\author{
Elena Puišiené $\dot{e}^{1}$, Rasa Ciegiené⿱ ${ }^{2}$ \\ Lietuvos kūno kultūros akademijal', Kauno Jono Basanavičiaus vidurinè mokykla², Kaunas, Lietuva
}

Elena Puišienė. Docentė socialinių mokslų daktarè. Lietuvos kūno kultūros akademijos Sporto pedagogikos ir psichologijos katedros docentė. Mokslinių tyrimų kryptis — asmens sveikata, fizinis pajėgumas, fizinis aktyvumas, fizinis ugdymas.

\section{SANTRAUKA}

Straipsnyje analizuojami kaimo pradiniu klasiu moksleiviu sveikatos ugdymo aplinkos aspektai. Sveikatos ugdymo aplinka sudaro šeima, mokykla, ugdytojas, jo sveikatos nuostata ir sveiko gyvenimo stilius, mokyklos sveikatos priežiūros sistema, kuriq reikia orientuoti sveikatos stiprinimo kryptimi, ir kt. Sveikatos ugdymo tikslai - teikti žiniu, ugdyti elgesi, igüdžius ir nuostatas, kurti reikalingq vertybiu sistema. Nuostata sudaro kognityviniu, emociniu ir veiklos komponentu derinys. Samoninga elgsenq lemia žmogaus nuostatos, požiūris, vertybinès orientacijos, kurios nèra igimtos, bet yra išugdomos ir gali kisti ugdymo procese (Jovaiša, 2001).

Tyrimo tikslas - nustatyti kaimo pradiniu klasiu moksleiviu sveikatos ir ju ugdytoju sveikatos nuostatos sqsajas. Uždaviniai: 1. Ištirti vaiku sveikata. 2. Nustatyti ugdytoju sveikatos bendraja nuostata ir jos komponentus: kognityvini, emociní, bihevioristinį. 3. Išsiaiškinti ugdytoju požiūrį i sveikata stiprinančius veiksnius. 4. Nustatyti koreliacinius ryšius tarp vaiku sveikatos negatyviosios dalies ir ugdytoju sveikatos nuostatos. Tyrimo metodai: 1. Literatūros šaltiniu analizè. 2. Dokumentu analize. 3. Anketine apklausa. 4. Matematinè statistika.

Tyrimas organizuotas vykdant p. A. Adamkienés fondo inicijuota projektq „Pagalba kaimo mokykloms “. Tiriamaja imtị sudare atsitiktiniu büdu parinktose 24 Lietuvos miesteliu ir kaimo mokyklose besimokantys 2316 pradiniu klasiu moksleiviai ir 122 ugdytojai, atsake i anketos klausimus. Rezultatai rodo, kad daugiausia negatyvios sveikatos kaimo mokyklu pradiniu klasiu moksleiviu yra Tauragès (79,1\%), Šiauliu (55,9\%), Kauno apskrityse (37,5\%). Daugiausia tarp kaimo pradiniu klasiu moksleiviu pasitaiko ydingos laikysenos (29,6\%), regos sutrikimu (19,4\%) ir širdies sisteminiu üžesiu (9,7\%) atveju. Pozityviausia bendroji sveikatos nuostata yra kūno kultūros mokytoju, toliau mokyklu vadovu, pradiniu klasiu mokytoju. Statistiškai reikšmingas skirtumas nustatytas tarp kūno kultūros ir pradiniu klasiu mokytoju grupiu vertinimu $(p<0,05)$. Tarp ugdytoju labiausiai išreikštas kognityvinis sveikatos nuostatos komponentas, t. y. žiniu turi pakankamai, o emocinis ir bihevioristinis komponentai išreikšti vienodai, t. y. emocijos ir elgsena, susijusi su sveikata, neadekvati turimoms žinioms. Ugdytojai išskiria tokius pagrindinius sveikatos veiksnius: sveikata - vertybe, mityba, sveiko gyvenimo stilius, o mažiau reikšmingi — sveikatos ugdymasis, sveikatos kontrole, gydymas, narkotikai, vaistai, veikla, susijusi su sveikata, sveikos aplinkos kūrimas ir fizinis aktyvumas. Esminis koreliacinis ryšys $(r=0,4)$ nustatytas tarp ugdytoju bendrosios sveikatos nuostatos bei jos bihevioristinio komponento ir mokiniu negatyviosios sveikatos. Kaimo pradinèse klasèse ryšys tarp ugdytoju sveikatos nuostatos ir mokiniu sveikatos yra menkas todèl, kad vaiku sveiko gyvenimo stiliui ir sveikatai didelès įtakos turi šeima.

Raktažodžiai: ugdytoju sveikatos nuostata, pradiniu klasiu mokiniu sveikata.

\section{IVADAS}

$\mathrm{P}$ radinukui reikia žinių, gerų pavyzdžių ir igūdžių, kad jis gebètų îvertinti negatyvius reiškinius, išsiugdytų teigiamas nuostatas, pajustų atsakomybę dèl savo ir kitų sveikatos. Pedagogo vaidmuo ugdant sveikatos igūdžius yra ypač reikšmingas (Sahlbergas, 1997). Kokią gyvenseną pasirinks besiformuojanti asmenybè, didelę itaką turi šeima, mokykla, visuomenè (Zaborskis ir kt., 1996; Blauzdys, 2002).

Nors biologiniu ir socialiniu požiūriu sveika- ta - didelè vertybè, tačiau jaunas žmogus nèra linkęs jos labai vertinti. Todèl nepaprastai svarbu sukurti ir išlaikyti šią nuostatą itvirtinančią aplinką, nes kitaip augantis žmogus perims antraeiles vertybes ir klaidingus vartotojiškus įsitikinimus (Zaborskis ir kt., 1996). Sveiko gyvenimo stiliaus formavimas nuo vaikystès yra labai svarbi sveikatos stiprinimo priemone.

Lietuvos sveikatos informacinio centro duomenimis, Vilniaus, Kauno, Klaipėdos, Šiaulių, Pane- 
vėžio, Alytaus, Marijampolès Tauragès, Telšių, Utenos apskrityse gausèja moksleivių, turinčiu regos, judamojo aparato, nervų sistemos sutrikimu.

Nuo mokytojo kaip ugdytojo požiūrio i̇ sveikatą daug priklauso, kaip jis pasirengs ir prisidès prie sveikatos ugdymo, kiek dèmesio ir kam skirs per pamokas, kokị požiūrị skiepys, kaip skatins mokinius tausoti sveikatą (Weare, Gray, 1995). Atsižvelgus į asmenybès nuostatas, konkrečiai i sveikatos, jas ivertinus, galima konkretinti ugdymą pagal nuostatos komponentus: kognityvini, emocini, bihevioristini.

Iki šiol sveikatos ir sveikos gyvensenos ugdymas mokyklose buvo stichiškas. Nuoseklus sveikatos ugdymas turètų būti susijęs su gyvensenos ypatumais ir poreikiu būti sveikiems. Neužtenka vien tik aiškinti, kas yra naudinga, o kas žalinga. Turi būti ugdomi atitinkami ipročiai ir igūdžiai, nuostatos, sudaroma galimybè rinktis tinkamą gyvenseną (Weare, Gray, 1995). Mokyklos gyvenimas bei aplinka gali ir turi tapti sveikatos ugdymą skatinančiu veiksniu (Zaborskis, Makari, 2001).

Moksleivių sveikatos ugdymo aplinka lemia ivairiausi veiksniai, tarp jų: mokykla, ugdytojų sveikatos nuostatos ir sveiko gyvenimo stilius, mokyklos sveikatos priežiūros sistema, kurią reikia orientuoti (Torrance, 1995) sveikatos stiprinimo kryptimi, šeima ir kiti aspektai.

Lietuvos mokinių, tarp jų ir pradinių klasių, sveikata kasmet blogejja. Ugdymo kryptingumas mokykloje (Education through Sport, 2004) turètu būti susijęs su mokinių sveikatos stiprinimo idèjomis ir sveiko gyvenimo ipročiu formavimu. Žinoma, kad pozityvesnè ugdytojo sveikatos nuostata lemia ir sveikesnio gyvenimo stiliu, o sveikesnis asmuo suinteresuotas išugdyti ir sveiką ugdytini. Tačiau pradinėse klasėse ryšys tarp ugdytojų sveikatos nuostatos ir mokiniu sveikatos dar yra menkas dèl tos priežasties, kad vaikų sveiko gyvenimo stiliui ir sveikatai didelę itaką turi šeima.

Lietuvoje pirminè sveikatos priežiūra mažiausiai apima: a) mokymą apie pagrindines sveikatos problemas ir metodus jų prevencijai kontroliuoti; b) sveiko maisto ir sveikos mitybos skatinima, c) sveikatos ugdymą ir mokymą. Todèl senają visuomenès sveikatos sistemą reikia keisti nauja ir būtina skirti ypatingą dèmesị šioms sveikatos stiprinimo veiklos rūšims: politikos formavimui, sveikatos vertinimui, sveikatos stiprinimui, remimui, sveikatos ugdymui ir mokymui, moksliniams tyrimas, bendradarbiavimui tarp sektoriu ir konsultavimui.
PSO, Europos tarybos bendrijos iškelta mintis, kad ,naujos Europos ateitis yra jos vaikai ir jiems turi būti duota galimybè augti sveikiems, siekti išsilavinimo, ugdyti sveikus igūdžius ir atsakomybès jausmą, kurie itin reikalingi dabartiniame pasaulyje“, yra aktuali ir Lietuvai.

Tyrimo tikslas - nustatyti kaimo pradiniu klasių moksleivių sveikatos ir jų ugdytojų sveikatos nuostatos sąsajas.

Tyrimo metu taikėme šiuos metodus: literatūros šaltinių analizę, dokumentų analizę, anketinę apklausą ir matematinę statistiką. Apskaičiuoti tokie statistiniai rodikliai: aritmetinis vidurkis $(\bar{x})$, vidutinis kvadratinis nuokrypis $(\sigma)$, aritmetinio vidurkio paklaida $(\bar{x} \pm S \bar{x})$, Stjudento kriterijus (t), Pirsono koreliacijos koeficientas (r). Skirtumu patikimumas laikytas reikšmingas, kai $\mathrm{p}<0,05$; esminis, kai $\mathrm{p}<0,01$; labai ryškus, kai $\mathrm{p}<0,001$; visiškas, kai $\mathrm{p}<0,0001$. Nustatant sąsajas tarp rodikliu, buvo taikomas Pirsono koreliacijos koeficientas (r).

Tiriamają imtị sudarè atsitiktiniu būdu parinktu 22 Lietuvos miestelių ir kaimo mokyklu (Tytuvènų (1), Garliavos Jonučių (2), Kruonio (3), Veisieju (4), Alsèdžių (5), Endriejavo (6), Vaškų (7), Sidabravo (8), Adutiškio (9), Žeimelio vidurinėse mokyklose (10); Dauglaukio (11), Drąsučiu (12), Skirsnemunès J. Baltrušaičio (13), Vilkyčiu (14), Medeikių (15), Judrènų Stepono Dariaus (16), Varlaukio J. Gudavičiaus (17), Pėžaičių (18), Paliepių (19), Šlienavos pagrindinèse mokyklose (20); Gustoniu pradinejje mokykloje (21); Linkaičių specialiojoje internatinejje mokykloje (22)) 2316 pradinių klasių moksleivių ir 122 anksčiau išvardytų kaimo mokyklų ugdytojai: iš jų 20\% mokyklų vadovų, $60 \%$ pradinių klasių mokytojų ir $20 \%$ kūno kultūros mokytojų, atsakiusių i anketos teiginius, suskirstytus $\mathfrak{i}$ tris sudedamąsias dalis (Žukowska, 2000; Puišienè, 2003).

Tyrimas organizuotas vykdant p. A. Adamkienès fondo inicijuotą projektą „Pagalba kaimo mokykloms".

\section{REZULTATAI}

Kaimo pradinių klasių moksleivių sveikata. Analizuojant tirtu 2316 moksleivių sveikatą nustatyta, kad iš jų ivvairiomis ligomis serga 830 moksleivių - tai sudaro 35,8\%. Endriejavo vidurinejje ir Dauglaukio pagrindineje mokyklose $100 \%$ mokiniu turi sveikatos sutrikimu (žr. 1 pav.), Tytuvėnu vidurinejje $-85,5 \%$, o per $30 \%$ tokiu 
1 lentelè. Mokinių sveikatos sutrikimai pagal ligas

\begin{tabular}{|c|c|c|c|c|c|}
\hline $\begin{array}{l}\text { Eil. } \\
\text { Nr. }\end{array}$ & Susirgimas & $\%$ & $\begin{array}{l}\text { Eil. } \\
\text { Nr. }\end{array}$ & Susirgimas & $\%$ \\
\hline 1. & Ydinga laikysena & 29,6 & 14. & Odos ligos & 1,9 \\
\hline 2. & Regèjimo sutrikimai & 19,4 & 15. & Judesių koordinacijos sutrikimai & 1,2 \\
\hline 3. & Sisteminiai širdies ūžesiai & 9,7 & 16. & Padidèjusios tonzilès & 1,2 \\
\hline 4. & Padidèjusi skydliaukè & 4,8 & 17. & Šlapimo nelaikymas & 1,1 \\
\hline 5. & Nutukimas & 4,7 & 18. & CNS sutrikimai & 0,7 \\
\hline 6. & Kalbos defektai & 4,2 & 19. & Mažas svoris & 0,7 \\
\hline 7. & Pèdų deformacija & 3,9 & 20. & Fizinio vystymosi sutrikimai & 0,6 \\
\hline 8. & $\mathrm{TBC}$ & 3,4 & 21. & Epilepsija & 0,4 \\
\hline 9. & Bronchinè astma & 2,5 & 22. & Kontaktas su TBC & 0,2 \\
\hline 10. & Skoliozè & 2,4 & 23. & Sąnarių hipermobilumas & 0,2 \\
\hline 11. & Protinio vystymosi sutrikimai & 2,4 & 24. & Mažakraujystė & 0,1 \\
\hline 12. & Funkciniai širdies ūžesiai & 2,3 & 25. & Padidejęs jautrumas & 0,1 \\
\hline 13. & Igimta širdies liga & 2,2 & & & \\
\hline
\end{tabular}

moksleiviu yra net devyniose vidurinèse mokyklose. Kitose mokyklose sutrikusios sveikatos moksleivių yra mažiau kaip 30\%.

Analizuojant sutrikusios sveikatos vaikų skaičiu pagal apskritis matyti (2 pav.), kad daugiau kaip puse tiriamuju yra Tauragès ir Šiaulių apskrityse, mažiausias procentas nustatytas Klaipèdos apskrityje.

Nustatytas toks mokiniu sergamumas pagal ligas: iš 35,8\% sergančiuju — 29,6\% mokiniu laikysena yra ydinga (3 pav.), 19,4\% turi regejimo sutrikimų, 9,7\% mokiniams būdingi sisteminiai ūžesiai, nutukimu serga $4,7 \%$ moksleivių, o skolioze $-2,4 \%$.

Likusios ligos sudaro 34,2\%. Tai bronchine astma, pedų deformacija, TBC, igimtos širdies ligos, protinio vystymosi sutrikimai ir kt. (žr. 1 lent.).

Ugdytojų bendrosios sveikatos nuostatos ir jos komponentų bei sveikatos veiksnių rezultatai. Pozityviausiai išreikšta bendroji kūno kultūros mokytojų sveikatos nuostata, o negatyviausiai - pradinių klasių mokytojų. Skirtumas statistiškai reikšmingas $(\mathrm{p}<0,05)(4$ pav.).

Lyginant sveikatos nuostatos komponentu rezultatus ( 5 pav.) matyti, kad tarp visu respondentu grupių vyrauja kognityvinis sveikatos nuostatos komponentas, kuri sudaro žinios apie sveikatą ir sveiką gyvenseną. Mokyklų vadovai ši sveikatos nuostatos komponentą vertina $73,5 \%$, panašiai kūno kultūros mokytojai - 73,3\%, o pradiniu klasių mokytojai - 72\%.

Tyrimo rezultatai parode, kad emocinis svei- katos nuostatos komponentas yra antras pagal reikšmingumą mokyklos vadovams $(61,9 \%)$, tačiau kūno kultūros ir pradinių klasių mokytojai reikšmingesniu laiko bihevioristini sveikatos nuostatos komponentą (atitinkamai: 63,5 ir 59,9\%). Trečias pagal reikšmingumą mokyklos vadovams yra bihevioristinis sveikatos nuostatos komponentas $(61,4 \%)$, o pradinių klasių ir kūno kultūros mokytojams - emocinis (atitinkamai: 59,6 ir $61,6 \%)$.

Atskirai nagrinėjome visu grupių respondentu požiūrị i pagrindinius sveikatą stiprinančius veiksnius: sveikata - vertybè, sveikatos ugdymasis, veikla, susijusi su sveikata, sveiko gyvenimo stilius, aplinkos kūrimas, mityba, narkotikų, vaistu prevencija, fizinis aktyvumas, sveikatos kontrolè (6 pav.). Matome, kad visų grupių tiriamiesiems svarbiausia vertybè - sveikata. Mokyklos vadovai ir pradinių klasių mokytojai antra pagal reikšmingumą laiko mitybą, trečia - sveiko gyvenimo stilių. Šios grupès tiriamieji mažiausiai reikšmès teikia sveikatos kontrolei, gydymui ir sveikatos ugdymui.

Kūno kultūros mokytojams svarbiausi sveikatos stiprinimo veiksniai yra: sveikata — vertybè, fizinis aktyvumas, paskui eina sveiko gyvenimo stilius ir mityba. Mažiausiai reikšmès kūno kultūros mokytojai, kaip ir mokyklų vadovai bei pradinių klasių mokytojai, skiria sveikatos saviugdai ir sveikatos kontrolei.

Moksleivių sveikatos ir ugdytojų prasminès sveikatos nuostatos koreliaciniai ryšiai. Analizuodami sveikatos nuostatos kognityvinio 
komponento ir sutrikusios sveikatos mokiniu sąsajas matome, kad tarp visų respondentų grupių ir mokinių sergamumo koreliacinio ryšio nèra (2 lent.). Vertinant šios sveikatos nuostatos tarpusavio koreliacinius ryšius tarp grupių akivaizdu, kad silpnas koreliacinis ryšys (atvirkštinis funkcinis) yra tarp mokyklų vadovų ir kūno kultūros mokytojų $(r=-0,248)$, pradinių klasių ir kūno kultūros mokytojų $(\mathrm{r}=-0,217)$ nuostatos.

Analizuodami emocini sveikatos nuostatos komponento ir sutrikusios moksleiviu sveikatos koreliacinius ryšius pastebime, kad tarp mokyklos vadovų šio sveikatos nuostatos komponento vertinimo ir mokiniu yra esminis koreliacinis ryšys $(\mathrm{r}=-0,457)$ (atvirkštinè priklausomybė) (3 lent.), tarp pradinių klasių mokytoju ir vaikų sergamumo yra silpnas koreliacinis (atvirkštinè priklauso-

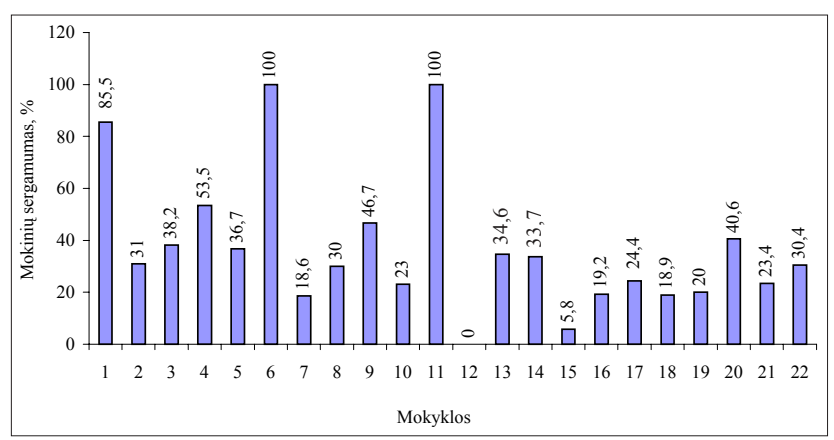

1 pav. Sergančių mokinių skaičius

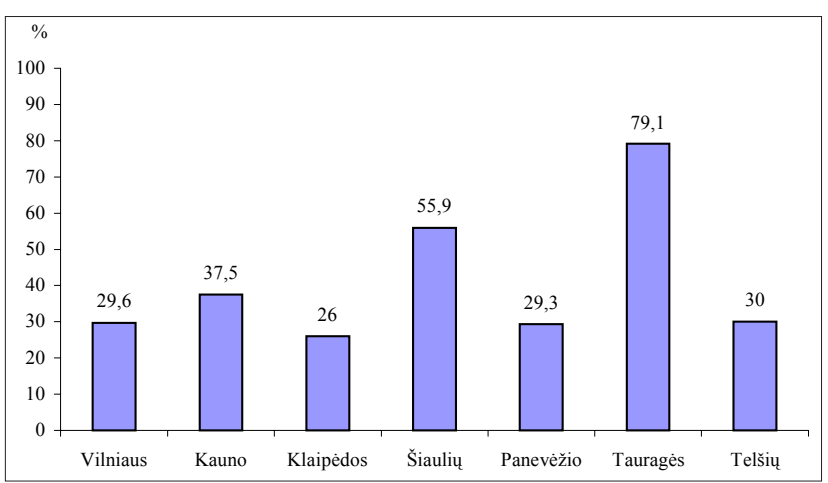

2 pav. Mokinių, turinčių sveikatos sutrikimų, skirstinys pagal apskritis

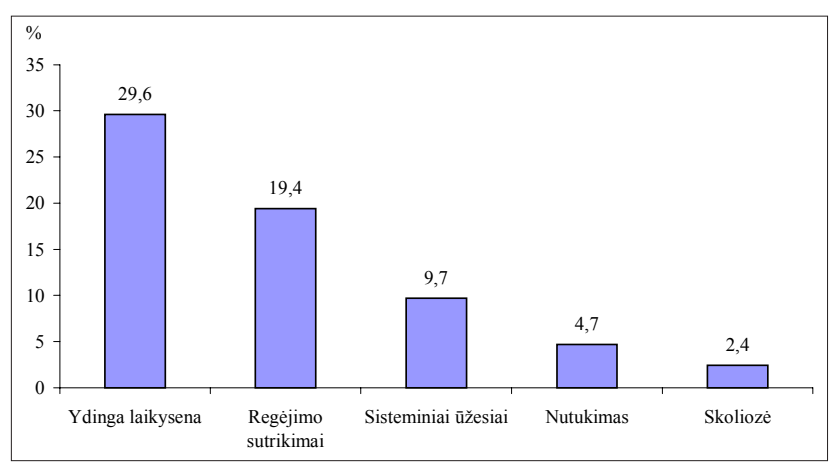

3 pav. Dažniausi mokinių sveikatos sutrikimai pagal ligas mybė) ryšys $(r=-0,309)$. Toks pat koreliacinis ryšys yra tarp kūno kultūros mokytojų ir moksleiviu sergamumo $(r=-0,331)$.

Vertinant sveikatos nuostatos emocinio komponento tarpusavio ryšius tarp respondentų grupių matyti, kad silpnas koreliacinis ryšys yra tarp mokyklų vadovų ir kūno kultūros mokytojų $(\mathrm{r}=0,221)$, pradinių klasių ir kūno kultūros mokytoju $(\mathrm{r}=0,245)$.

Analizuodami bihevioristini sveikatos nuostatos komponentą ir moksleivių sergamumo koreliacinius ryšius matome, kad tarp mokyklos vadovu šio sveikatos nuostatos komponento vertinimo ir sergančių mokiniu yra silpnas (atvirkštinè priklausomybė) koreliacinis ryšys $(r=-0,340)$ (4 lent.). Esminius koreliacinius ryšius (atvirkštinè priklausomybè) pastebime tarp pradiniu

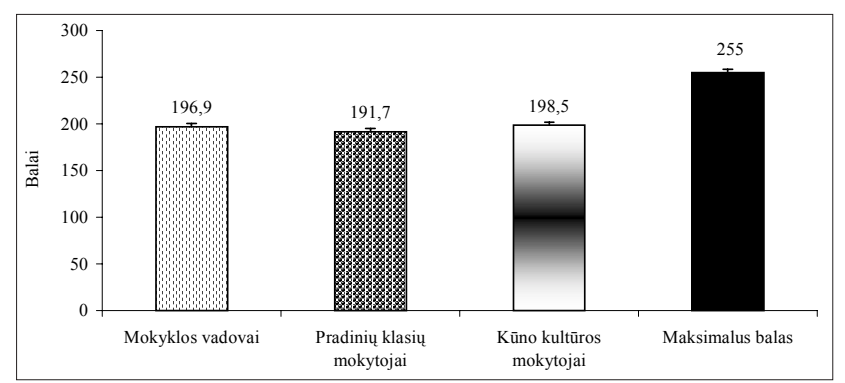

4 pav. Ugdytojų bendrosios sveikatos nuostatos rezultatai

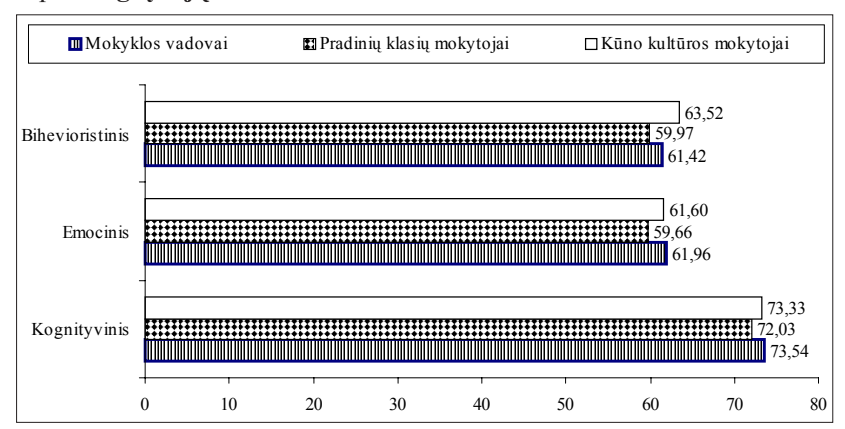

5 pav. Ugdytojų bendrosios sveikatos nuostatos komponentų rezultatai

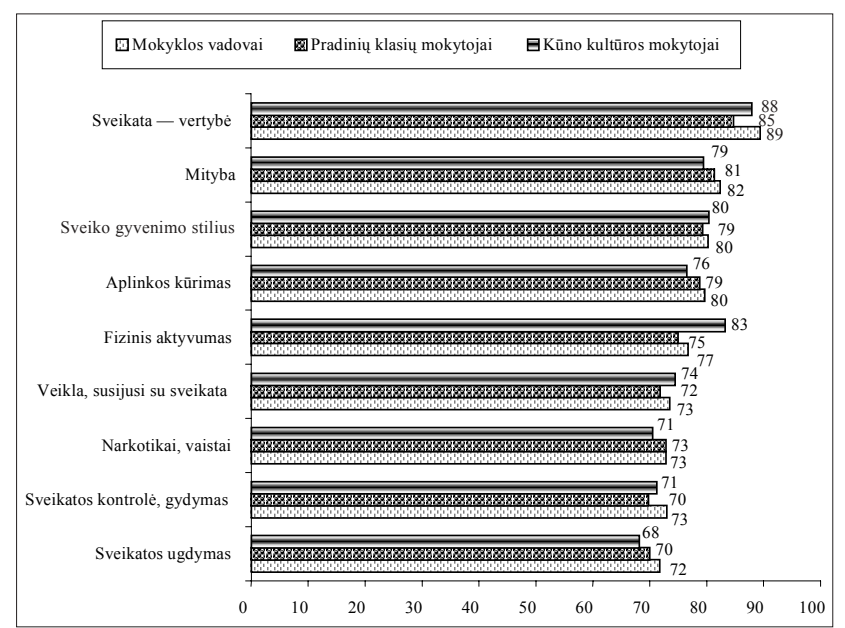

6 pav. Ugdytojų sveikatos stiprinimo veiksnių rezultatai (\%) 


\begin{tabular}{|c|c|c|c|c|c|}
\hline \multirow{5}{*}{$\begin{array}{l}2 \text { lentelè. Kognityvinio kom- } \\
\text { ponento įverčių ir sutrikusios } \\
\text { sveikatos vaikų koreliacinis } \\
\text { ryšys }\end{array}$} & Tiriamieji & $\begin{array}{l}\text { Mokyklos } \\
\text { vadovai }\end{array}$ & $\begin{array}{l}\text { Pradinių klasių } \\
\text { mokytojai }\end{array}$ & $\begin{array}{l}\text { Kūno kultūros } \\
\text { mokytojai }\end{array}$ & $\begin{array}{l}\text { Sergančių } \\
\text { vaikų dalis }\end{array}$ \\
\hline & $\begin{array}{l}\text { Mokyklos } \\
\text { vadovai }\end{array}$ & 1 & & & \\
\hline & $\begin{array}{l}\text { Pradinių klasių } \\
\text { mokytojai }\end{array}$ & $-0,182$ & 1 & & \\
\hline & $\begin{array}{l}\text { Kūno kultūros } \\
\text { mokytojai }\end{array}$ & $-0,248$ & 0,217 & 1 & \\
\hline & $\begin{array}{l}\text { Sutrikusios sveikatos } \\
\text { vaikai }\end{array}$ & $-0,165$ & $-0,064$ & $-0,074$ & 1 \\
\hline \multirow[t]{5}{*}{$\begin{array}{l}3 \text { lentelè. Emocinio komponen- } \\
\text { to įverčių ir sutrikusios svei- } \\
\text { katos vaikų koreliacinis ryšys }\end{array}$} & Tiriamieji & $\begin{array}{c}\text { Mokyklos } \\
\text { vadovai }\end{array}$ & $\begin{array}{c}\text { Pradinių klasių } \\
\text { mokytojai }\end{array}$ & $\begin{array}{c}\text { Kūno kultūros } \\
\text { mokytojai }\end{array}$ & $\begin{array}{l}\text { Sergančių } \\
\text { vaikų dalis }\end{array}$ \\
\hline & \begin{tabular}{|l} 
Mokyklos \\
vadovai
\end{tabular} & 1 & & & \\
\hline & $\begin{array}{l}\text { Pradinių klasių } \\
\text { mokytojai }\end{array}$ & 0,109 & 1 & & \\
\hline & $\begin{array}{l}\text { Kūno kultūros } \\
\text { mokytojai }\end{array}$ & 0,221 & 0,245 & 1 & \\
\hline & $\begin{array}{l}\text { Sutrikusios sveikatos } \\
\text { vaikai }\end{array}$ & $-0,457$ & $-0,309$ & $-0,331$ & 1 \\
\hline \multirow{5}{*}{$\begin{array}{l}4 \text { lentelè. Bihevioristinio kom- } \\
\text { ponento įverčių ir sutrikusios } \\
\text { sveikatos vaikų koreliacinis ry- } \\
\text { šys }\end{array}$} & Tiriamieji & $\begin{array}{l}\text { Mokyklos } \\
\text { vadovai }\end{array}$ & $\begin{array}{c}\text { Pradinių klasių } \\
\text { mokytojai }\end{array}$ & $\begin{array}{c}\text { Kūno kultūros } \\
\text { mokytojai }\end{array}$ & $\begin{array}{l}\text { Sergančių } \\
\text { vaikų dalis }\end{array}$ \\
\hline & $\begin{array}{l}\text { Mokyklos } \\
\text { vadovai }\end{array}$ & 1 & & & \\
\hline & $\begin{array}{l}\text { Pradinių klasių } \\
\text { mokytojai }\end{array}$ & 0,158 & 1 & & \\
\hline & $\begin{array}{l}\text { Kūno kultūros } \\
\text { mokytojai }\end{array}$ & 0,288 & 0,283 & 1 & \\
\hline & $\begin{array}{l}\text { Sutrikusios sveikatos } \\
\text { vaikai }\end{array}$ & $-0,340$ & $-0,441$ & $-0,486$ & 1 \\
\hline \multirow{5}{*}{$\begin{array}{l}5 \text { lentelè. Ugdytojų bendrosios } \\
\text { sveikatos nuostatos kompo- } \\
\text { nentŭ ir sutrikusios vaikų } \\
\text { sveikatos koreliacinis ryšys }\end{array}$} & Tiriamieji & $\begin{array}{l}\text { Mokyklos } \\
\text { vadovai }\end{array}$ & $\begin{array}{l}\text { Pradinių klasių } \\
\text { mokytojai }\end{array}$ & $\begin{array}{c}\text { Kūno kultūros } \\
\text { mokytojai }\end{array}$ & $\begin{array}{l}\text { Sergančių } \\
\text { vaikų dalis }\end{array}$ \\
\hline & $\begin{array}{l}\text { Mokyklos } \\
\text { vadovai }\end{array}$ & 1 & & & \\
\hline & $\begin{array}{l}\text { Pradinių klasių } \\
\text { mokytojai }\end{array}$ & 0,029 & 1 & & \\
\hline & $\begin{array}{l}\text { Kūno kultūros } \\
\text { mokytojai }\end{array}$ & 0,332 & 0,254 & 1 & \\
\hline & $\begin{array}{l}\text { Sutrikusios sveikatos } \\
\text { vaikai }\end{array}$ & $-0,382$ & $-0,385$ & $-0,467$ & 1 \\
\hline
\end{tabular}

klasių mokytojų sveikatos nuostatos ir moksleivių sergamumo $(\mathrm{r}=-0,441)$, kūno kultūros mokytoju sveikatos nuostatos ir mokiniu sergamumo $(r=-0,486)$. Vertindami bihevioristinio sveikatos nuostatos komponento tarpusavio koreliacinius ryšius tarp grupiu pastebime silpnus kūno kultūros mokytojų ir pradinių klasių mokytojų sveikatos nuostatos $(\mathrm{r}=0,283)$, mokyklos vadovų ir kūno kultūros mokytojų sveikatos nuostatos $(r=0,288)$ koreliacinius ryšius.
Analizuojant bendrosios sveikatos nuostatos komponentu sumos ir mokiniu sergamumo koreliaciją matyti, kad egzistuoja esminis koreliacinis ryšys (atvirkštinè priklausomybė) tarp kūno kultūros mokytojų ir mokinių sergamumo $(r=-0,467)$ (5 lent.). Silpnas koreliacinis ryšys (atvirkštinè priklausomybè) pastebimas tarp mokyklos vadovu ir mokiniu sergamumo $(\mathrm{r}=-0,382)$, pradinių klasių mokytojų ir mokinių sergamumo $(r=-0,385)$.

Analizuojant koreliacinius ryšius tarp ugdyto- 
jų bendrosios sveikatos nuostatos, jos komponentų, sveikatą stiprinančių veiksnių ir moksleivių negatyviosios sveikatos nustatyta, kad esminis koreliacinis ryšys yra tarp moksleivių negatyviosios sveikatos ir mokyklos vadovų emocinio sveikatos nuostatos komponento $(r=-0,457)$ bei šiu sveikatą stiprinančių veiksnių: sveiko gyvenimo stiliaus $(r=0,428)$, fizinio aktyvumo $(r=-0,430)$ vertinimo.

\section{REZULTATŲ APTARIMAS}

Kaime gyvenantys vaikai savo sveikatą vertina blogiau nei miestiečiai (Zaborskis ir kt., 1996). Lietuvos 11-15 metų amžiaus mergaitès dažniau jaučiasi nelaimingos negu berniukai, vyresni moksleiviai dažniau nei jaunesni.

Atliktas tyrimas rodo, kad kaimo pradiniu klasiu moksleiviai serga net 25 ligomis - tokiomis kaip ydinga laikysena, regos sutrikimai, sisteminiai širdies ūžesiai ir kt. Nustatème, kad kaimo pradinių klasių moksleivių negatyvioji sveikata silpnai $(r=0,4)$, bet koreliuoja su ugdytojų sveikatos saviugda, sveikos aplinkos kūrimu ir mityba.

Sveikatos ugdymas - tai kryptingos ir sąmoningos pastangos gilinti žinias apie sveikatos saugojimo ir stiprinimo būdus, ugdyti pozityvias sveikatos ir elgesio nuostatas, skiepyti sveikus elgesio igūdžius (Weare, Gray, 1995). Tai glaudžiai susiję su ligų profilaktika. Sveikatos ugdymas yra platesnis ir gilesnis procesas negu sveikatos mokymas (Gage, Berliner, 1994; Zaborskis, Petrauskaite, 2000). Moksleivių sveikatos ugdymo aplinka lemia ivairiausi veiksniai, tarp jų ir ugdytojų sveikatos nuostatos, šeima, medicininès priežiūros tarnyba, žmonès (mokytojai, vietinio verslo vadovai, vietos valdžios institucijų darbuotojai, gydytojai ir seselès), kurių tikslas garantuoti geresnę sveikatą ir kovoti su sveikatos nelygybe (Weare, Gray, 1995; McCarthy, 2003).

Labai svarbu mokyti vaikus saugoti sveikatą ir ją stiprinti, iškelti sveikatos prioritetą vertybiu sistemoje (The Physical Self. From Motivation to Well-Being, 1997; Zuozienè, 1998). Sveikatos ugdymas ypač prasmingas ir efektyvus vaikysteje, paauglysteje, kai formuojasi žmogaus pasaulèjauta ir elgsenos stereotipai, dar netvirti žalingi ipročiai (rūkymas, fizinio aktyvumo stoka, prasti higienos igūdžiai). Ši darbą lydès sèkmè tik tada, kai bus sutelktos visuomenès, medikų, pedagogų, šeimos ir individo pastangos (Ozmon, Craver, 1996; Sahlbergas, 1997). Tyrimai rodo, kad 24,7\% kaimo moksleivių sveikos gyvensenos žinių igyja per kūno kultūros pamokas (Kardelis ir kt., 2001), kur kas daugiau moksleivių — 44,4\% — sužino per kitų dalyku pamokas.

Sąmoningą elgseną lemia žmogaus nuostatos, požiūris, vertybinès orientacijos, kurios nèra igimtos, bet yra išugdomos ir gali kisti ugdymo procese (Jovaiša, 2001). Daugelis tyrimų rodo, kad nuostatos pasikeitimas - sudètingas procesas, dažnai sukeliantis iliuzijas, netinkamus poelgius, vidinius prieštaravimus ir neigiamas emocijas (Žukowska, 2000).

Irodyta, kad tarp sveikos gyvensenos nuostatos komponentų yra statistiškai reikšminga priklausomybè (Žukowska, Dąbrowski, 1998), t. y. sveikesni ir sveiką gyvenseną praktikuojantys asmenys yra pozityvesni, lyginant juos su asmenimis, turinčiais ne tokias palankias šio kultūrinio reiškinio nuostatas (Zabotkienè, 2000; Puišienė, Stasiulevičienè, 2001). Aktyvi asmens ugdymo strategija reikšmingai lemia ne tik nuostatas, bet ir elgseną, kurios dèka gerèja gyvenimo būdas, stilius (Žukowska, 1997; Kalèdienè ir kt., 1999).

Atliktas tyrimas rodo, kad pozityviausią bendrają sveikatos nuostatą turi kūno kultūros mokytojai, paskui mokyklų vadovai ir pradinių klasių mokytojai. Tarp ugdytojų labiausiai išreikštas kognityvinis sveikatos komponentas, o tarp emocinio ir bihevioristinio komponentų skirtumo nèra $(\mathrm{p}>0,05)$.

Iš tyrimo rezultatu galima daryti išvadą, kad kaimo ugdytojai išskiria šiuos sveikatą stiprinančius veiksnius: sveikata - vertybè, sveiko gyvenimo stilius, aplinkos kūrimas bei mityba, o kūno kultūros mokytojams yra aktualus ir fizinis aktyvumas. Jie labiausiai vertina tokius sveikata palaikančius veiksnius: sveikata — vertybè $(88 \%)$, fizinis aktyvumas $(83 \%)$ ir sveiko gyvenimo stilius $(80 \%)$. Mokyklų vadovu grupejje išskiriama: sveikata - vertybè $(89 \%)$, mityba (82\%) ir sveiko gyvenimo stilius (80\%). Pradinių klasių mokytojams aktualiausi tokie sveikata stiprinantys veiksniai: sveikata - vertybè $(85 \%)$, mityba $(81 \%)$, sveiko gyvenimo stilius ir aplinkos kūrimas (po $79 \%)$.

Fizinis aktyvumas (Bouchard et al., 1994; Wankel, Sefton, 1994; Shields, Bredemeier, 1995; Whitehead, Corbin, 1997), ypač jei ji tinkamai parinksime ir dozuosime, padeda mažinti sergamumą išemine širdies liga, cukriniu 
diabetu ir insultu (Leon \& Connett, 1991; Fizinis aktyvumas: gyvenimo igūdžiu pamokos, 2004), turi itakos sveikatos pagerejimui, ilgina sveiko ir produktyvaus gyvenimo trukmę, o nepakankamas fizinis aktyvumas jaunysteje laikomas gana svarbus veiksnys, didinantis galimybę susirgti vyresniame amžiuje (Blair et al., 1989; The Physical Self. From Motivation to Well-Being, 1997).

Sveikatos ugdymo sėkmę lemia ir paties vaiko nusiteikimas, jo požiūris į save, individualios asmens savybès, amžius. Pateikiant tam tikrųžinių ir taikant pedagoginius ir psichologinius mokymo būdus, galima pakeisti arba suformuoti teigiamą prasminę nuostatą (Puišienè, Stasiulevičienè, 2001). Pamažu vaikų nuostatos perauga i elgesi, kuris turi įtakos jų pozityviajai sveikatai (Adaškevičienė, 1999). Didžia dalimi vaikų sveikatą lemia ugdymo procesas: pedagogo elgsena ir gyvensena, ugdymo institucijos aplinka ir kiti dalykai, daug priklausantys nuo pedagogo (Hopkins et al., 1998).

Esminis koreliacinis ryšys nustatytas tarp vaiku negatyviosios sveikatos dalies ir pradinių klasių mokytojų sveikatos nuostatos bihevioristinio komponento $(r=-0,441)$ bei tokių sveikata stiprinančių veiksnių kaip sveiko gyvenimo stilius $(r=-0,425)$, mityba $(r=0,401)$, narkotiku, vaistu prevencija $(r=0,511)$, fizinis aktyvumas $(\mathrm{r}=0,447)$, sveikatos kontrolè ir gydymasis $(\mathrm{r}=-0,542)$ vertinimo.

Taip pat tarp moksleiviu negatyviosios sveikatos ir kūno kultūros mokytojų bihevioristinio sveikatos nuostatos komponento $(\mathrm{r}=-0,486)$, bendrosios sveikatos nuostatos $(\mathrm{r}=-0,467)$ bei šiu sveikatos veiksnių: sveikatos ugdymosi $(r=0,567)$, veiklos, susijusios su sveikata $(r=-0,550)$, vertinimo.

\section{IŠVADOS}

1. Didžiausias kaimo mokyklų pradinių klasių sutrikusios sveikatos moksleiviu skaičius nustatytas Tauragès apskrityje - 79,1\%, toliau Šiaulių (55,9\%), Kauno (37,5\%). Išaiškintos 25 ligos, kuriomis serga pradinių klasių moksleiviai. $29,6 \%$ pradinių klasių moksleivių laikysena yra ydinga, 19,4\% būdingi regos sutrikimai ir $9,7 \%$ - sisteminiai širdies ūžesiai.

2. Pozityviausią bendrosios sveikatos nuostatą turi kūno kultūros mokytojai, toliau - mokyklų vadovai, pradinių klasių mokytojai. Statistiškai reikšmingas bendrosios sveikatos nuostatos skirtumas nustatytas tarp kūno kultūros ir pradinių klasių mokytojų $(\mathrm{p}<0,05)$. Apskritai tarp ugdytojų labiausiai išreikštas kognityvinis sveikatos nuostatos komponentas, t. y. žinių turi pakankamai, o emocinis ir bihevioristinis komponentai yra išreikšti vienodai - emocijos ir elgsena, susijusi su sveikata, neadekvati turimoms žinioms.

3. Ugdytojai išskiria tokius pagrindinius sveikatą stiprinančius veiksnius: sveikata — vertybè, mityba, sveiko gyvenimo stilius. Mažiau reikšmingi jiems yra šie: sveikatos ugdymasis, sveikatos kontrole, gydymasis, narkotikų, vaistų prevencija, kita veikla, susijusi su sveikata, sveikos aplinkos kūrimas ir fizinis aktyvumas.

4. Kaimo pradinių klasių moksleivių sveikata priklauso nuo jų ugdytojų bendrosios sveikatos nuostatos ir jų elgsenos. Esminis koreliacinis ryšys $(r=0,4)$ nustatytas tarp ugdytoju bendrosios sveikatos nuostatos ir jos bihevioristinio komponento bei mokiniu negatyviosios sveikatos. Kaimo pradinių klasių moksleivių negatyvioji sveikata stipriai koreliuoja su ugdytoju sveiko gyvenimo stiliumi, narkotiku ir vaistu prevencija, fiziniu aktyvumu, sveikatos kontrole ir gydymusi, su kūno kultūros mokytojų sveikatingumo veikla ir sveikatos saviugda, su pradinių klasių mokytojų mityba. 


\section{LITERATŪRA}

Adaškevičienè, E. (1999). Vaiku sveikatos ugdymas. Vilnius.

Bitinas, B. (1998). Ugdymo tyrimu metodologija. Vilnius. Blair, S. N., Clark, D. G., Cureton, K. J. \& Powell, K. E. (1989). Perspectives in Exercise and Sports Medicine (Vol. 2: "Youth, exercise and sport"). New York.

Blauzdys, V. (2001). Darželinuku ir moksleiviu fizinio ugdymo kaita.: mokymo priemone. Vilnius: VPU 1-kla.

Blauzdys, V. (2002). Naujoviška kūno kultūros pamoka. Vilnius: VPU 1-kla.

Bouchard, C., Shepard, R. J., Stephens, Th. (Eds.). (1994). Physical Activity, Fitness, and Health. International Proceedings and Consensus Statement. Champaign, III: Human Kinetics Publishers.

Education through Sport. An Overview of Good Practices in Europe. (2004). J. Janssens et al. (Eds.). The Netherlands, Nieuwegein: Publisher Michel van Troost, Anko Sport Media.

Fizinis aktyvumas: gyvenimo igūdžiu pamokos. (2004). Studiju knyga. Parengè V. Volbekienè. Vilnius: Lietuvos sporto informacijos centras.

Gage, N., Berliner, D. (1994). Individualus mokymas ir humanistinis ugdymas. Pedagogine psichologija. Vilnius: Alma litera. P. 361-396.

Gečaitè, J. (1997). Sveikatos programos Šiauliu krašte. Sveikatos stiprinimas vaiku ugdymo institucijose: I nacionalinès konferencijos medžiaga. Šiauliai: ŠPU. P. 19-22.

Hopkins, D., Ainscow, M., West, M. (1998). Kaita ir mokyklos tobulinimas. Vilnius: Tyto alba.

Jovaiša, L. (2001). Ugdymo mokslas ir praktika: analitiniu straipsniu monografija (pp. 60-86). Vilnius.

Kaledienè, R., Petrauskienè, J., Rimpela, A. (1999). Šiuolaikinio visuomenes sveikatos mokslo teorija ir praktika. Kaunas.

Kardelis, K., Kavaliauskas, S., Balzeris, V. (2001). Mokyklinè kūno kultūra: realijos ir perspektyvos. Kaunas.

Leon, A. S. \& Connett, J. (1991). Physical activity and 10.5 year mortality in the Multiple Risk Factor Intervention Trial (MRFIT). International Journal of Epidemiology, 20, 690-697.

McCarthy, M. (2003). Visuomenès sveikatos priežiūra Didžiojoje Britanijoje: tarptautinès konferencijos ,,Bendruomenès sveikatos labui" medžiaga. Kaunas.

Ozmon, H., Craver, S. (1996). Filosofiniai ugdymo pagrindai. Vilnius: Leidybos centras.

Puišienè, E. (2003). Pedagogu sveikos gyvensenos nuostata. Ugdymas. Küno Kultūra. Sportas, 5, 53-56.

Puišienė, E., Stasiulevičienè, L. (2001). Būsimuju sporto ugdytojų sveikatos nuostata. Ugdymas. Küno Kultūra. Sportas, 3, 35-40.

Sahlbergas, P. (1997). Mokymasis bendraujant. Mokykla, $5,15-18$.

Shields, D. L. L., Bredemeier, B. J. L. (1995). Character
Development and Physical Activity. Champaign, III: Human Kinetics.

The Physical Self. From Motivation to Well-Being. (1997). K. Fox (Ed.). Champaign, III: Human Kinetics. P. 175204.

Torrance, E. P. (1995). Rewarding Creative Behavior in Classroom Activity. Englewood Cliffts, New York: Prentice-Hall.

Wankel, L. M., Sefton, J. M. (1994). Physical activity and other lifestyle behaviors. In C. Bouchard, R. J. Shepard, Th. Stephens (Eds.), Physical Activity, Fitness, and Health. International Proceedings and Consensus Statement. Champaign III: Human Kinetics Publishers.

Weare, K., Gray, G. (1995). Protinès ir emocinès sveikatos stiprinimas Europos sveikatos mokyklu tinkle: mokymo priemone. Vilnius: Informacijos ir leidybos centras.

Whitehead, J., Corbin, C. (1997). Self-esteem in children and youth: The role of sport and physical education. In K. R. Fox, The Physical Self. From Motivation to WellBeing. Champaign III: Human Kinetics. P. 175-204.

Zaborskis, A., Makari, J. (2001). Lietuvos moksleiviu gyvensena: raida 1994-1998 metais ir vertinimas tarptautiniu požiūriu (pp. 49-90). Panevėžys.

Zaborskis, A., Petrauskaitè, A. (2000). Aukime sveiki. Sveikatos ugdymas vaikų darželyje. Auklètojo knyga (pp. 11-35). Kaunas.

Zaborskis, A., Žemaitiene, N., Šumskas, L. ir kt. (1996). Moksleiviu gyvenimo būdas ir sveikata. Vilnius. P. 123.

Zabotkienè, D. (2000). 18-23 m. amžiaus studenčiu sveikatos nuostatu ir fizinio pajégumo ryšys: magistro tezès. Kaunas: LKKA.

Zuozienè, I. J. (1998). Kūno kultūros ir sveikos gyvensenos žiniu itaka moksleiviu fiziniam aktyvumui: daktaro disertacija. Kaunas: Lietuvos kūno kultūros akademija.

Žukowska, Z., Dąbrowski, A. (1998). Potrzeba werifikacji ksztalcenia nauczycieli z perspektywy pedagogiki humanistycznej. Torunskie studia dydaktyczne, Rok. VII (12), 39-49. Torun.

Žukowska, Z. (2000). Ja zdrowie ruch. Paradnik dla mlodziezy, rodzicow i nauczycieli. Warszawa.

Žukowska, Z. (1997). Rozwoj pedagogiki humanistyscznej a promocja zdrowia. Nauki o wychowaniu a promocja zdrowia. Olsztyn: WSp. 


\title{
THE CORRELATION OF HEALTH OF PRIMARY SCHOOLCHILDREN IN VILLAGES AND HEALTH ATTITUDE OF TEACHERS
}

\author{
Elena Puišienè ${ }^{1}$, Rasa Ciegiené⿱2 \\ Lithuanian Academy of Physical Education ${ }^{1}$, Kaunas Jonas Basanavičius Secondary School ${ }^{2}$, Kaunas, \\ Lithuania
}

\begin{abstract}
The health of Lithuanian schoolchildren, including the primary school pupils who live in villages, is getting worse and worse every year. Education at schools should include the ideas of health improvement and healthy lifestyle. The positive teacher's attitude towards his / her health influences his/her lifestyle. But the relation between a teacher's healthy life style and his / her pupils' health yet cannot be clearly seen. The aim of this research is to identify the aspects of health education of primary school children who live in villages. The objectives of the research are the following: 1 . To analyze reasons of children's morbidity; 2 . To identify teacher's general attitude towards health and its cognitive, emotional and behaviouristic components; 3. To identify teachers' attitudes towards health improving components; 4 . To identify the relationship between children's morbidity and the teachers' attitude towards health.

The research is a part of the project called "Support for Schools in Villages" which was initiated by Mrs Alma Adamkiene's Fund. The research was carried out in 24 schools in small Lithuanian towns and villages. 2316 primary school pupils and 122 teachers took part in it.

The following conclusions were made after the analysis of the results of this research. The highest level of morbidity among primary class pupils was determined in Taurage district (79\%). Šiauliai district is in the second place (55.9\%). Meanwhile, Kaunas district is in the third place (37\%). 25 diseases are mostly spread among the primary school children. They are the following: incorrect set, poor eyesight, scoliosis, physical growth disorder, hyper sensitivity, functional bruit, systemic bruit, asthma, tuberculosis and others. 29.6 per cent of primary school children have incorrect set. The other 19.4 per cent of pupils have poor eyesight. 9.7 per cent of them suffer from systemic bruit.

Teachers of physical education have the most positive attitude towards health. They are followed by the head teachers and primary school teachers. The research shows that the teachers have enough knowledge concerning healthy lifestyle, but they are not effectively used. The most important health elements, according to the teachers are the following: nourishment and healthy lifestyle. Such elements as health control, healing, medicine, drugs, activities that improve health condition, healthy environment and physical activity seem to be of less importance for them.

The correlative relations were noticed among a teacher's attitude, behavioristic component and children's morbidity. In primary schools in villages this relationship is dim because parents and school environment still have a great influence.
\end{abstract}

Keywords: health attitude of teachers, health of primary schoolchildren in villages. 